\title{
CARBON DIOXIDE UNDER HIGH PRESSURE: A SAFE METHOD FOR THE STORED GRAIN PEST MANAGEMENT
}

\author{
K. B. SUBBIREDDY ${ }^{1}$, K. G. KANJARIYA ${ }^{2}$ \& A. N. THARUN ${ }^{3}$ \\ ${ }^{I}$ Department. of Entomology, BACA, AAU, Anand, Gujarat, India \\ ${ }^{2}$ Department. of Genetics and Plant Breeding, BACA, AAU, Anand, Gujarat, India \\ ${ }^{3}$ Department. of Plant Physiology, BACA, AAU, Anand, Gujarat, India
}

\begin{abstract}
Today, one of the main global challenges is how to ensure food security for a growing world population. Globally, India is the second most populated country after china, in order to feed the extraneous population the concern towards food safety, security and quality, increasing day by day from producer to consumer aiming to do hunger free country. Agriculture is mainly depending on climate and the farmers are facing hectic constraints from farm to till it reached to fork. Post-harvest losses of food grains in India are 7-10 per cent of the total production and the losses in storage is mainly due to insect pests associated with grains in order solve the problem the techniques which are more prevalently in use are heat treatment and fumigation with chemicals but there are only few available fumigants. In addition, there are environmental concerns and low level of resistance to phosphine exists in stored grain insects. This leading to affect the grain quality and increases insecticide residues resulting difficulties in the long run. The permanent solution to solve the many problems by exposure of relevant development stages of major stored grain insects to high concentrations of carbon dioxide around (98\%) for short intervals (5-20 minutes) produce maximum mortality. Thereafter, work is concentrating on modified atmosphere and hermetic storage.

KEYWORDS: Carbon Dioxide, Pest, Storage \& Fumigant
\end{abstract}

Received: May 07, 2017 ; Accepted: Jun 01, 2017 ; Published: Jun 13, 2017 ; Paper Id.: IJASRJUN201755

\section{INTRODUCTION}

Agriculture solely dependent on climate, in order to meet the hunger our farmers are facing many problems farm and post-harvest it includes during processing, storage, transport, etc., Among this, insect pest wipe out grain lots in storage resulting huge losses. Presently, many tactics are in use to circumvent the losses, it includes heat treatment, solar treatment, chemical application, fumigation etc., but, these will result grain quality and increase the problem of resistance, resurgence, residue in food stuffs leads to the long term arrest of human life. In order exclude situation. There are increasing restrictions on the use of pesticides and on the number of chemical compounds officially registered for pest control in durable food products. Moreover, the use of methyl bromide for the fumigation of food commodities and facilities must be phased out in accordance with the Montreal Protocol due to its effect on the ozone layer (UNEP, 2006). The development of alternative treatments for pest control is an increasing demand from the food industry and has been promoted by governments through legislation and the funding of research projects. Alternatives should meet consumer demands for the reduced use or elimination of pesticides while at the same time maintaining a high degree of control efficacy. The increase in attention of food safety and security non-thermal processes have gained increasing importance in recent years, as a potentially treasured technology, to replace or at least complement the traditional processes currently in use for 
microbial and insectpestinactivation. The traditional techniques, having many downsides such as retention of flavour, denaturation of nutrients, production of side toxic reactions as well as changes in physical, mechanical and optical properties of the material involved in the treatment Konig et al., 1997; Nair, 1995). Because of well-documented problems with reliance on synthetic pesticides, viable alternatives are sorely needed. There are many safe methods were in use to swipe the pest problems in storage. Among them, the use of $\mathrm{CO} 2$ under pressure appears to be the most promising technique. This opportunity was first addressed in the 1950s by Fraser (Fraser, 1951) and Foster (Foster et al., 1962) who reported about the disruption of bacteria cells by the rapid release of CO2 gas from a pressure of $500 \mathrm{lbf} / \mathrm{in} 2$ (about $34 \mathrm{~atm}$ ) to ambient pressure.

\section{NEED OF HIGH PRESSURED CARBON DIOXIDE}

The controlled atmosphere would be one of the safest control strategies for the stored-grain +9-protection. +99999+99, it needs longer exposure times to control the insect pests, compared to those required for conventional fumigants. To overcome this, the application of $\mathrm{CO}_{2}$ at a high pressure, that kills insects quickly due to both the high concentration of $\mathrm{CO}_{2}$ and damage to internal tissues. The method was successfully scaled up using a rotary valve system, which allowed continuous treatment of large amounts of grain in a short time. Thus, the method is considered as a promising alternative to fumigants. (Nakatika et al., 2001). The mechanism of action on target insects is not fully understood.. However, it is well known that the solubility of gases increases at higher pressures. Thus, the toxic action of carbon dioxide could have been enhanced by its greater solubility in hemolymph leading to better penetration and great interaction at sites of action. (Stahl et al., 1985) elucidated that treatment acts by increasing the respiration and solution in internal liquids. In addition, destroys cell membranes during rapid decompression. So that it is a potential and feasible alternative for quick

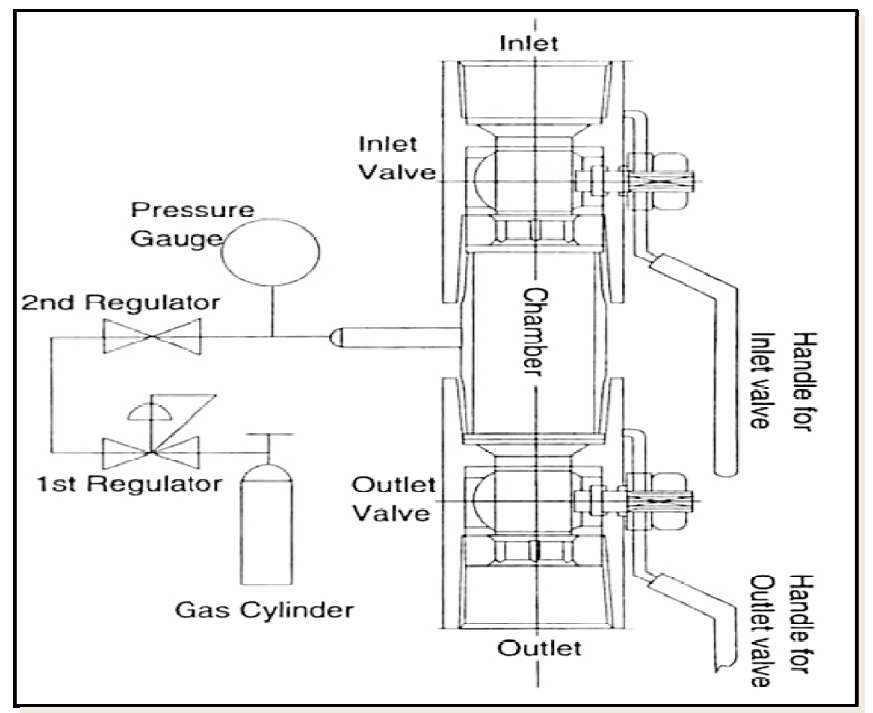

Figure 1: Schematic Diagram of Carbon Dioxide Treatment under High Pressure

Disinfestations of agricultural commodities, mainly for quarantine treatment of exported and imported grain commodities. In addition, this technique also poses minimal risk to workers, leaves no harmful residue and environmentally safe. 


\section{EFFECT OF HIGH PRESSURED $\mathrm{CO}_{2}$ ON DIFFERENT LIFE STAGES OF INSECTS}

The development of alternative treatments for pest control in food commodities is an increasing demand from the food industry, which should meet consumer demands for the reduced use or elimination of pesticides. The use of carbon dioxide $\left(\mathrm{CO}_{2}\right)$ at high pressure is one of the most rapid options for arthropod pest control among current commercial treatments, offering complete control within hours. Modified atmospheres based on mixtures of gases with high carbon dioxide $\left(\mathrm{CO}_{2}\right)$ content are known to be effective for the switch of stored-product pests that affect raw materials and semiprocessed and final food products (Adler et al., 2000; Navarro, 2006). When used at atmospheric pressure, modified atmosphere treatments may take from a few days to several weeks to be successful in controlling all the developmental stages of pests, with this depending on gas concentrations and temperatures (Riudavetset al., 2009). The exposure of Callosobruchus maculatus (F.) eggs at different ages. To $\mathrm{co}_{2}$ pressures (5, 10, 15 and 30 bar) with 5, 10, 15 and 20 min exposure revealed that one-day-old eggs were found to be the most tolerant, requiring 30 bars and 20min exposure for complete extermination. On the other hand, five-day-old eggs were the least tolerant, requiring only 20 bars and 10min (Hassan et al., 2004). According to Quirin et al., 1988, Indian meal moth and Acarus Siro (flour mite), a 100\% mortality of pest insects was guaranteed after a treatment time, in the range of 5-120 minutes, depending on the pressure applied and the stage of the insect's development. Noticed the antimicrobial effect of dense $\mathrm{CO}_{2}$ on different kind of insect pests, bacteria and fungi and emphasized the potential of this technique both in pest control of food storage and in the sterilization in pharmaceutical and foodstuff processing. High concentrations of carbon dioxide retained in well-sealed enclosures have been used to control stored product insects in food commodities, particularly grain (Jay, 1986) and insects infesting museum artifacts (Burke 1993). The carbon dioxide exposure periods found necessary for complete control of Sitophilus oryzae and Triboliumcastaneum as per the report of Annis (1987), who formulated the durations of exposure to $60 \%$ carbon dioxide required to obtain at least $95 \%$ mortality in these species at 20 to $29^{\circ} \mathrm{C}$. However, Prozell and Reichrnuth (1991) subjected all stages of S. Granaries to 99\% carbon dioxide at 20 bars and achieved total control with three, two and one hour exposure at 10,20 , and $30^{\circ} \mathrm{C}$ respectively and stated that eggs were the most tolerant stages. Nakakita and Kawashima, 1994. Revealed the effect of various pressures and exposure periods was assessed against Sitophilus zeamais, Rhyzopertha Dominica, Lasioderma silicone and Tribolium castanium with $\mathrm{CO}_{2}$ at $20 \mathrm{~kg} / \mathrm{cm}^{2}$, exposure time of $5 \mathrm{~min}$. was sufficient to kill adults of all four species. However, eggs of $S$. zeamais, required treatment at $30 \mathrm{~kg} / \mathrm{cm}^{2}$ of $\mathrm{Co}_{2}$ for $5 \mathrm{~min}$ for complete mortality. The integument of insects exposed to this treatment was severely damaged because of expansion of internally dissolved $\mathrm{CO}_{2}$ in the body when gas pressure was rapidly equilibrated with atmospheric pressure. In contrast, the application had no effect on adults of $S$. zeamais even at $70 \mathrm{~kg} / \mathrm{cm}^{2}$. Riudavets et al., 2010 results shows the high level of control for most species and development stages when they were treated with $\mathrm{CO}_{2}$ at 20 bar for 60 min. However, the efficacy at 15 bars was much lower. The eggs of L. bostrychophila and L. serricorne showed the highest tolerance of all species/stages and survived the most extreme conditions tested. The beetle $O$. surinamensis, the moth E. kuehniella, and the mite T. putrescentiae were easier to kill than the other species tested. The above results confirmed that the use of high-pressure $\mathrm{CO} 2$ offers an effective and fast way to control most stored-product pests that affect food commodities.

\section{HERMETIC SEED STORAGE}

The technology facilitates farmers to store their own seed for long periods without any losses due to insect pests and without using any chemicals. The technology consists of enclosing the seed in airtight containers that prevent or 
minimize gas exchange. Insect aerobic respiration depletes $\mathrm{O}_{2}$ and increases $\mathrm{CO}_{2}$. Insect feeding stops, and therefore insects begin dying (Murdock et al., 2012). This technique can maintain seed quality for up to one year of storage. Seed must be dry prior to storage, approximately $12-14 \%$ moisture. Drying seed is a real challenge in the humid tropics. High moisture contents in hermetically stored grain such as maize can lead to loss in germination and viability and thus dryness must be ensured (Weinberg et al., 2007). The simplicity and viability of hermetic storage are resulting in significant adoption, but it cannot be assumed that farmers are already employing this technology everywhere and correctly. In many parts of the world farmers are also using pesticides. It is therefore, important to underscore both necessary (drying, proper sealing, avoiding bag puncture risk) and unnecessary practices (insecticide supplements) in hermetic storage.

\section{Economic Advantages of Hermetic Storage Includes}

- $\quad$ Reduced physical losses

- $\quad$ Ability to sell seed (and grain) over a longer period and achieve a better price

- Improved quality of seed leading to lower seeding rates

- Improved plant vigor, and ultimately improved yields.

\section{CONCLUSIONS}

Concerning hermetic pigeon pea seed storage, Vales (2013) compared storage in PICS (Purdue improved crop storage) and gunny sacks and reported $1 \%$ brushed infestation with PICS compared to $17 \%$ infestation in gunny sacks. They also report $88 \%$ germination in PICS compared to $69 \%$ in gunny sacks and increased seedling vigor in PICS, measured as increased length of the seedling radicle and plumule.

\section{REFERENCES}

1. Adler, C., Corinth, H.G. Reichmuth, C. (2000). Modified Atmospheres, Bh. Subramanyam, D.W. Hagstrum (Eds.), Alternatives to Pesticides in Stored-product IPM, Kluwer Academic Publishers, MA, USA (2000), pp. 105-146.

2. Annis, P. C. (1991). Tolerance to carbon dioxide in Sitophilus oryzae Proc. 5th Int. Working Conf. on Stored-Product Protection, Bordeaux, France, September, 1990 (ed. Fleurat-Lessard F and Duwm P), 2: 737-745.

3. Burke, J. (1993). Brief overview of current research into the control of bio deterioration through the use of thermal or suffocant conditionsAmerican Institute for Conservation News, 18(2): 1-5.

4. Foster, J. W., Cowan, R. M. and Maag, T. A. (1962). Rapture of bacteria by explosive decompression. J. Bacteriol.,83: 330334.Fraser, D. (1951). Bursting bacteria by release of gas pressure. Nature,167: 33-34.

5. Hassan, S. M. V., Taro, I. Akihiro, M. (2004). Mortality of eggs of the cowpea bruchid, Callosobruchus maculatus (F.)(Coleoptera : Bruchidae) in carbon dioxide under high pressure. Applied Ent.\&Zool.,39(1): 49-53.

6. Jay, E. C. (1986). Factors affecting the use of carbon dioxide for treating raw and processed agricultural products GASGA Seminar on Fumigation Technology in Developing Countries, Tropical Development and Research Institute, Slough, UK, 1986 pp 173-189.

7. Konig, C., Ruffieux, K., Wintermantel, E. and Blaser, J. (1997). Autosterilization of bio degradable implants by injection molding process. J. Biomed. Mat. Res.,38(2): 115-119. 
8. Nair, P. D. (1995). Currently practised sterilization methods - Some inadvertent consequences. J. Biomater. Appl.,10(2):121135.

9. Nakakita, H. and Kawashima, K. A new method to control stored-product insects using carbon dioxide with high pressure followed by sudden pressure loss. Proceedings of the 6th International Working Conference on Stored-Product Protection, April 1994, Canberra, Australia. 1: 126-129.

10. Nakakita, H., Ikenaga, H. and takahashi, K. (2001). Disinfestation of stored grains using high-pressure carbon dioxide. Donahaye, E.J., Navarro, S. and Leesch J.G. [Eds.] (2001) Proc. Int. Conf. Controlled Atmosphere and Fumigation in Stored Products, Fresno, CA. 29 Oct. - 3 Nov. 2000, Executive Printing Services, Clovis, CA, U.S.A pp. 421-430.

11. Navarro, S. (2006). Modified atmospheres for the control of stored product insects and mites J.W. Heaps (Ed.), Insect Management for Food Storage and Processing, AACC International, St. Paul, Minnesota, USA (2006), pp. 105-145.

12. Prozell, S. and Reichmuth. C. (1991). Response of the granary weevil Sitophilus granarius(L.)(Col.: Curculionidae) to controlled atmospheres under high pressure Proc. 5th Inr. Working Conf. on Stored-Product Protection, Bordeaux, France, September 1990 (ed. Fleurat-Lessard F and Ducom P), 2: 911-919.

13. Quirin, K. W., Stahl, E. and Gerard, D. (1988). Dense gases fur extraction and refining. Berlin: Springer Verlag. $p 218-223$.

14. Riudavets, J., Castane, C., Alomar, O., Pons, M. J. and Gabarra, R. (2009). Modified Atmosphere Packaging (MAP) as an alternative measure for controlling ten pests that attack processed food products. J.Stored Products Res.,45: 91-96.

15. Stahl, E., Rau, G. and Adophi, H. (1985). Entwesung von Drogen durch Kohlendioxid-Druck-Behandlung (PEX-Verfahren). Pharmazeutische Industrie, 47, 528-530.

16. UNEP (United Nations Environment Programme)(2006). Report of the Methyl Bromide Technical Options Committee(MBTOC).Assessment/http://www.unep/ozone/teap/Reports/Teap_Reports. (2006).

17. Riudavets, J., Castane, C., Alomar, O., Pons, M. J. and, Gabarra, R. (2010). The use of carbon dioxide at high pressure to control nine stored-product pests. J. Stored Products Res., 46: 228-233.

18. Riudavets, J., Castane, C., Alomar, O., Pons, M.J.and Gabarra, R. (2009).Modified Atmosphere Packaging (MAP) as an alternative measure for controlling ten pests that attack processed food products. Journal of Stored Products Research, 45: 91-96.

19. Murdock. L. L., Margam, V., Baoua, I., Balfe, S. and Shade, R. E. (2012). Death by desiccation: Effects of hermetic storage on cowpea bruchids. J. Stored Products Res.,49: 166-170.

20. Weinburg, Z.G., Yan, Y., Chen,Y. Finkelman, S. Ashbell, G. and Navarro, S. (2007). The effect of moisture level on highmoisture maize (Zea mays L.) under hermetic storage conditions-in vitro studies. J. Stored Products Res.,44(2): 136-144.

21. Vales, M.I. (2014) Effective and economic storage of pigeonpea seed in triple layer plastic bags. J. Stored Products Res.,58: 29-38. 
